\title{
Macroalgal growth on bivalve aquaculture netting enhances nursery habitat for mobile invertebrates and juvenile fishes
}

\author{
Monica J. Powers ${ }^{1,2}$, Charles H. Peterson ${ }^{1, *}$, Henry C. Summerson ${ }^{1}$, Sean P. Powers ${ }^{1,2}$ \\ ${ }^{1}$ Institute of Marine Sciences, University of North Carolina at Chapel Hill, Morehead City, North Carolina 28557, USA \\ ${ }^{2}$ Present address: Dauphin Island Sea Lab, Dauphin Island, Alabama 36528, USA
}

\begin{abstract}
Destruction and degradation of biogenic nursery habitats, such as seagrass and coral/ oyster/polychaete reefs, threaten coastal fisheries worldwide. We tested the hypothesis that macroalgae and epifauna growing upwards from protective plastic mesh used in bottom clam culture substitutes for seagrass as a nursery habitat for mobile invertebrates and juvenile fish. By quantifying biomass of epibiota in each season and by seining both day and night on 11 occasions from August 1997 to April 1999, biogenic habitat structure and habitat use by mobile invertebrates and juvenile fishes were quantified on hard clam Mercenaria mercenaria aquaculture leases that were using 2 alternative grow-out methods and on 2 natural habitats, a seagrass bed (Zostera marina and Halodule wrightii) and an unstructured sandflat. The macroalgal/epifaunal biomass per unit bottom area was significantly greater on aquaculture mesh than on the sandflat but did not differ significantly from the natural seagrass biomass density on most sampling dates. Community structure of mobile invertebrates and juvenile fishes utilizing clam leases was more similar to that of seagrass than sandflat habitats. Community similarity among the structured habitats, the seagrass and the 2 lease types, was greater than the similarity between night and day within any given habitat. The total numbers of mobile invertebrates summed over all 11 dates were 75 times greater in the seagrass than in the sandflat habitat, whereas the structural habitat provided by epibiota attached to bottom mesh on leases provided a 44 -fold enhancement of invertebrates over the corresponding counts on unstructured sandflat. Utilization by juvenile fishes was 3 times greater in seagrass and 3 to 7 times greater in epibiota on mesh in clam leases than on sandflat habitat. For example, juvenile reef fishes exhibited almost equal utilization of epibiota on leases and seagrass while remaining absent over the sandflat, which lacked emergent structure. Thus, the biogenic habitat provided largely by macroalgal growth on protective bottom mesh of clam leases supports elevated densities of mobile invertebrates and juvenile fishes similar to that of natural seagrass habitat, thereby representing a previously undocumented ecosystem benefit of bivalve aquaculture. This ecological role for structural habitat rising above clam aquaculture leases is consistent with a broader recognition that artificial reefs, plastic seagrass, oyster shell mounds, and other emergent bottom structures provide habitat services.
\end{abstract}

KEY WORDS: Nursery habitat · Juvenile fishes $\cdot$ Macroalgae $\cdot$ Seagrass $\cdot$ Hard clam $\cdot$ Mercenaria mercenaria $\cdot$ Bivalve aquaculture

Resale or republication not permitted without written consent of the publisher

\section{INTRODUCTION}

Worldwide, extractive fishing is responsible both for collateral damage to estuarine and coastal seafloor habitats from bottom-disturbing gear and practices (Jennings \& Kaiser 1998, Tegner \& Dayton 1999) and for depletion of many targeted and untargeted species, especially larger animals at higher trophic levels (Pauly et al. 1998). In principle, well designed and managed aquaculture could serve growing world demand for seafood products without the attendant widespread degradation of natural seafloor habitats 
from dredges and trawls and without negative ecosystem consequences arising from over-exploiting natural stocks. In practice, however, aquaculture has been shown to have induced its own serious environmental impacts, including coastal habitat destruction where marshes and mangroves are allowed to be converted into culture pens (Silvert \& Sowles 1996) and where organic wastes from high-density culture operations fall to the bottom and induce anoxia during their microbial degradation (Paez-Osuna et al. 1998). In addition, because many aquaculture operations target predatory crustaceans and fishes and the necessary protein sources for feed are often most efficiently obtained by extracting bait fishes from natural ecosystems, aquaculture also can have negative impacts on natural coastal ecosystems from over-exploitation of these smaller forage species (Goldburg \& Triplett 1997 , Naylor et al. 2000).

One solution suggested to solve the problem of potentially unsustainable extraction of forage fishes to feed predatory crustaceans and fishes is to promote aquaculture of organisms at lower trophic levels, specifically macroalgae, sea urchins, sea cucumbers, and bivalves (Kaiser et al. 1998), which may often provide positive ecosystem services (Jackson et al. 2001). Both macroalgae and suspension-feeding bivalves have potential to counteract (e.g. Newell 2004) some of the consequences of perhaps the most insidious type of estuarine and coastal ocean ecosystem degradation, eutrophication (Nixon 1995). Macroalgae assimilate inorganic nutrients and can thereby help limit the system-degrading microalgal blooms that result from excess nutrient loading by a range of human activities (Paerl et al. 1998). Bivalve aquaculture, a process by which juveniles of suspension-feeding species are grown to market size in the estuary or coastal ocean (typically by using some form of predator protection such as mesh nets or cages; Kraeuter et al. 1998), can also help control excess growth of these microalgae through direct grazing. Such interactions between trophic levels constitute the ecosystem basis for sustainable polyculture (Folke \& Kautsky 1989), in which potentially problematic production of inorganic nutrients or algae are transformed into a nutritional benefit for one or more partner species.

Although bivalve aquaculture requires consideration of the water body's carrying capacity for both provisioning of food and processing of wastes so as to avoid ecosystem degradation, bivalves can provide several positive ecosystem services (Goldburg \& Triplett 1997, Lenihan \& Peterson 1998, Newell 2004) that can be promoted through aquaculture. Deposition of fecal and pseudofecal materials can induce denitrification, thereby converting excessive loads of inorganic N nutrients to inert nitrogen gas (Newell 2004), although overloading by such biodeposits can cause oxygen depletion if culture densities exceed the system's carrying capacity for organic loading. Water filtration of suspension-feeding bivalves feeding in shallow embayments can reduce turbidity (Alpine \& Cloern 1992), a water-quality parameter that is unnaturally elevated by both sedimentation from land development (Cooper \& Brush 1993) and eutrophication (Paerl et al. 1998). Reduction of turbidity can in turn promote growth of seagrasses, thus indirectly enhancing a limited nursery habitat in coastal systems (Newell \& Koch 2004). Bivalve aquaculture operations also indirectly provide biogenic habitat in the form of macroalgae and epifauna growing on mesh devices used to contain and protect the juvenile bivalves. Although the habitat benefits of such epibiotic growth on aquaculture mesh have not yet been documented (and algal proliferation could be so dense as to induce anoxia during decomposition in stagnant water: Thrush 1986), the importance of macroalgal habitat, including within seagrass beds, as nurseries for mobile invertebrates and juvenile fishes (Bell et al. 1995, Guidetti 2000) suggests that this created habitat may help replace the services of declining natural vegetation. Engineered hard structures in marine environments have already been shown to provide analogous habitat augmentation: pilings of docks, ship wrecks, artificial reefs, plastic seagrass, and oil-andgas platforms are colonized by diverse communities of invertebrates and used by numerous fishes and other mobile organisms (Bell et al. 1985, Hay \& Sutherland 1988, Love et al. 2005).

Here we assess the degree to which protective netting used in estuarine bivalve aquaculture provides useful biogenic habitat for juvenile fishes and mobile invertebrates by serving as substratum for macroalgal and epifaunal growth. We employ field sampling designed to evaluate the relative degree to which active clam leases serve as nursery habitat by quantifying (1) biogenic structure, and (2) habitat utilization by mobile invertebrates and juvenile fish. By comparing use of structured habitat facilitated by the presence of bottom netting with use of naturally occurring sandflat (largely unstructured) and seagrass (vertically structured) habitats, we test whether mobile invertebrate and juvenile fish communities are enhanced through indirect consequences of installing bottom netting on originally unstructured sandflat habitat and how closely they resemble the naturally structured seagrass communities. We also contrast 2 clam grow-out methods differing in predator-exclusion strategy: an open lease consisting solely of clam plots covered by bottom mesh, and a fenced lease where identically mesh-covered clam plots are also enclosed by a vertically oriented predator-exclusion fence. 


\section{MATERIALS AND METHODS}

Study design. The sampling sites required to make our intended contrasts were established in conjunction with a clam grow-out lease operated by Carolina Cultured Shellfish. The lease covered subtidal bottom within a shallow (from $0.2 \mathrm{~m}$ at low to $1.5 \mathrm{~m}$ at high tide) embayment along the margin of Westmouth Bay on the north side of Harkers Island, Carteret County, NC, USA (Fig. 1). Although clam aquaculture operations also exist at other locations within North Carolina estuaries, we limited our study to Westmouth Bay because only this was large enough to present a unique opportunity of comparing leased areas to sandflat and seagrass habitats within the same embayment. Despite this limitation to a single bay, the large area encompassed ( 0.5 to $1 \mathrm{~km}^{2}$ ) by each of the 4 habitat types was sufficient for replicate subsamples to be distributed over wide areas, thereby reflecting a range of variation within each habitat and achieving a large measure of independence. The 4 habitat types were non-contiguous, separated by $\sim 500$ to $1000 \mathrm{~m}$, and located more than $100 \mathrm{~m}$ from the shoreline or any other vegetated or structured habitat. The leased sites were of 2 types, open and fenced. The open lease consisted of a sandflat modified by establishment of 50 to 60 clam plots (each $3.6 \times 8 \mathrm{~m}$ ), containing multiple $6 \mathrm{~mm}$ polypropylene mesh bags stocked with clams at a range of standard culture densities, all covered by $12 \mathrm{~mm}$ polypropylene mesh. The finer mesh was needed to retain the seed clams when they were first planted in March, but it was deemed insufficient protection from blue crabs, so the coarser mesh was added on top. Mesh remained in place from

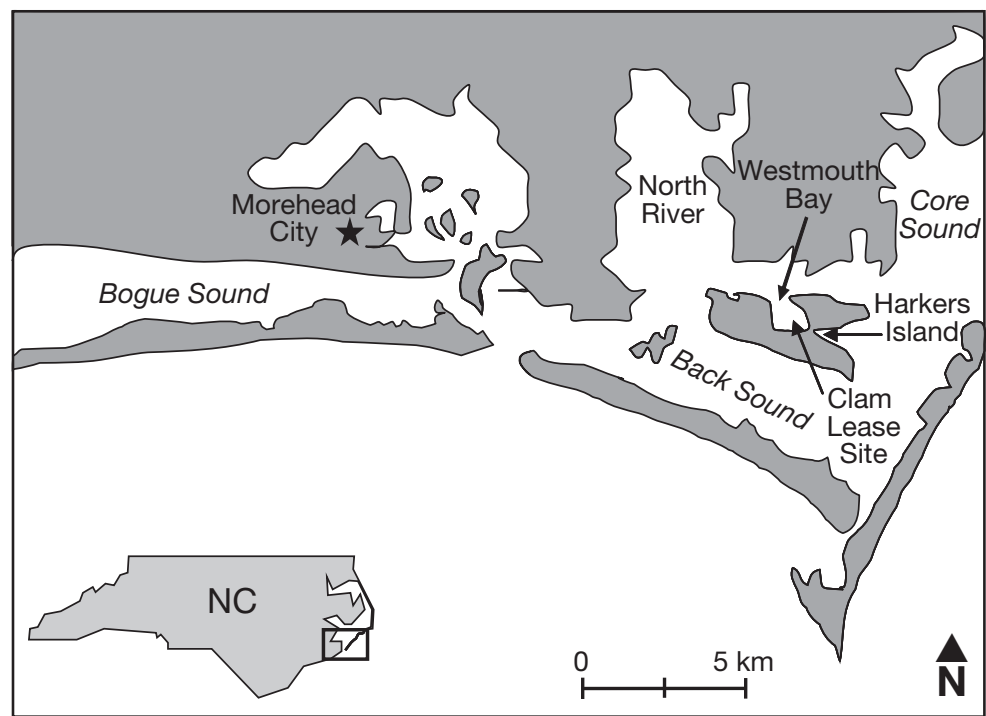

Fig. 1. Bogue, Back, and Core Sounds, North Carolina, USA. All 4 habitat types (fenced lease, open lease, seagrass, sandflat) were located within Westmouth Bay to the north of Harkers Island
March 1997 until harvesting of the enclosed clams, which occurred after termination of our sampling (typically about $3 \mathrm{yr}$ in this area). No mesh cleaning was done in this operation because of concerns over labor costs and absence of evidence for need of intervention during grow-out to sustain clam growth and survival. The fenced lease had an identical arrangement of clam plots and meshes on the bottom but was additionally surrounded by a $5 \mathrm{~cm}$ mesh fence that extended from below the sediment surface to an elevation that projected above the water surface. The fence was designed to exclude seasonally migrating cownose rays Rhinoptera bonasus, which can consume large numbers of bivalves and apparently target high-density shellfish beds (Peterson et al. 2001). The seagrass habitat consisted of a mixture of eelgrass Zostera marina and shoal grass Halodule wrightii, whereas the sandflat habitat was an homogeneous unvegetated plain. Water depth did not differ across the 4 habitat types.

Comparison of habitat structure. To determine the degree to which each habitat type provided emergent biogenic structure that might serve as habitat for mobile invertebrates and juvenile fish, we quantified the biomass of all epibiota within the 4 habitat types (fenced lease, open lease, seagrass, sandflat) every 3 mo so as to sample each of the 4 seasons (October 1997 and January, April, and June 1998). Biogenic material consisted of seagrass, the attached fouling community (comprised largely of macroalgae but also including some erect epifauna), and seasonally varying associated drift algae.

Biogenic biomass was collected by first anchoring a $10 \times 10 \mathrm{~cm}$ quadrat to the substrate surface. A buoyant $1 \mathrm{~mm}$ mesh enclosure was attached to the quadrat to prevent loss of materials during sampling. A Venturi vacuum pump with a $5 \mathrm{~cm}$ diameter intake hose was then inserted through an opening in the top of the mesh enclosure and all epibiota was vacuumed into a $1 \mathrm{~mm}$ mesh bag, gently washed, and preserved in 10\% formalin. This device had been shown to be effective in extracting all seagrass in previous work (e.g. Peterson et al. 1987) and was found to sample even the more delicate epifauna like erect bryozoans without loss of fragments through the mesh. In clam leases, the quadrat was placed on the mesh clam bags such that all macroalgae and epifauna could be effectively extracted. On each sampling date, we sampled 3 quadrats within each of 3 randomly selected meshcovered clam plots at each lease site. Three quadrats were also collected within 3 randomly established $3.6 \times 8 \mathrm{~m}$ areas in the 
seagrass and sandflat habitats to maintain comparable sampling designs. The contents of the 3 quadrats in each plot or area were treated as subsamples and averaged to form 1 of the 3 replicate samples per treatment $\times$ season combination. In the seagrass habitat, any remaining seagrass (including roots and rhizomes) within the quadrat was extracted by hand after suctionsampling. The sandflat habitat occasionally contained attached macroalgal or epifaunal growth on scattered shells, which was also quantified by our sampling process. In the laboratory, biogenic material was separated from any sand or shell, dried at $80^{\circ} \mathrm{C}$ for $24 \mathrm{~h}$, and the aggregate weighed and converted to g dry wt $\mathrm{m}^{-2}$.

Quantification of habitat use by mobile invertebrates and juvenile fishes. We conducted both day and night seine surveys in 11 mo (August, September, October 1997; January, April, June, October, December 1998; February, March, April 1999) to evaluate the use of each habitat type by mobile invertebrates and (predominantly) juvenile fishes. The seine was $4 \mathrm{~m}$ wide $\times$ $1.2 \mathrm{~m}$ tall with an attached $1.2 \times 1.2 \mathrm{~m}$ center mesh bag of $3 \mathrm{~mm}$ delta-mesh. Six replicate sampling sites were randomly established and marked with temporary PVC posts within each habitat type $24 \mathrm{~h}$ prior to each sampling period. At each sampling site, a $9 \mathrm{~m}$ distance was seined on a rising tide during the day and again at night at new locations. At the end of each seine haul animals were trapped by bringing each wing of the seine together to form a circle. All contents were then forced into the bag of the seine, collected, and preserved with $10 \%$ formalin for later identification and quantification. Fish and decapod invertebrates were counted and identified to species, and remaining invertebrates (e.g. mud crabs, grass shrimp) were also identified to species, except when juvenile (then to genus).

Data analyses. ANOVA was used to compare habitat structure (defined as biomass of biogenic structural habitat) among the 4 habitat types. We used Statview Version 5.0 (SAS Institute) software to perform a 2-way factorial ANOVA on the aggregate biogenic $g$ dry weight $\mathrm{m}^{-2}$ to test for variation of habitat structure among seasons (fixed factor: fall 1997, winter, spring, and summer 1998), habitat types (fixed factor: fenced lease, open lease, seagrass, sandflat), and their interaction. Cochran's $C$-test was performed prior to ANOVA to test for homogeneity of variances $(\alpha=0.05)$; $\operatorname{Ln}(x+1)$ transformation was applied to meet this assumption. When the interaction between season and habitat proved significant, post hoc contrasts of habitat means within each season were performed using the StudentNeuman-Keuls (SNK) test (after Day \& Quinn 1989).

We evaluated similarities in the multivariate assemblages of mobile invertebrates and juvenile fishes collected during day and night seine surveys among the 4 habitat types by conducting non-metric multidimen- sional scaling (nMDS) using PRIMER Version 5 software (Clarke \& Warwick 2001). All 8 habitat $\times$ time groupings were compared: fenced lease-day, fenced lease-night, open lease-day, open lease-night, seagrass-day, seagrass-night, sandflat-day, sandflatnight. Abundance data for each taxon were averaged by sampling date for each habitat $\times$ time grouping and ordinations were done on centroids of these untransformed means using the 11 replicate dates. BrayCurtis measures of dissimilarity were applied to quantify and prepare 2-dimensional plots of the differences among assemblages.

In comparing abundances of mobile invertebrates and juvenile fishes among the 4 habitat types, we first analyzed total mobile invertebrates and then total fishes. To examine more specific patterns of habitat use and facilitate the application of our results to fisheries, we subdivided these 2 broad categories. Specifically, we divided invertebrates into 2 assemblages (Table 1) based on whether a taxon was a target of fishing. The unexploited invertebrate assemblage included small epibenthic taxa, such as decapod shrimps and mud crabs. The fished invertebrate assemblage included penaeid shrimps, blue crabs, and Florida stone crabs. We subdivided the fish into 6 assemblages (Table 1) based on a combination of factors including relative abundance, fisheries management considerations, and selected life-history traits. Pinfish Lagodon rhomboides were placed into a single group because their abundance was high enough to mask signals from other group members. Sciaenids and reef fishes were placed into 2 separate groups because of their fisheries significance. The reef fishes constituted species that live as adults largely on off-shore reefs, although adults of some species like sheepshead also occupy estuarine oyster reef habitat. Pelagic fishes formed a separate group because they were least likely to have a close association with benthic habitats. The remaining taxa were separated into benthic transients (whose juvenile and adult habitats do not entirely overlap) and benthic residents (who spend the vast majority of their life within a single habitat).

We used Statview Version 5.0 software to conduct 3-way factorial ANOVAs to test the effects of sampling date (fixed factor: 11 sampling dates approximately every 2 mo from August 1997 to April 1999), habitat type (fixed factor: fenced lease, open lease, seagrass, sandflat), sampling time (fixed factor: day, night), and their 3- and 2-way interactions on the untransformed mean densities for the 10 groupings (total invertebrates, total fish, 2 invertebrate assemblages and 6 fish assemblages). Because one could argue that day- and night-time abundances are not independent and because most higher-order interactions involving sampling time were statistically significant, we next analy- 
Table 1. Taxonomic composition of assemblages used as dependent variables in 3- and 2-way ANOVAs run on contents of seine samples. Total invertebrates $=$ unexploited plus exploited invertebrates; Total fish $=$ sum of pinfish, sciaenids, pelagic fishes, reef fishes, benthic transients and benthic residents. Assemblages and taxa within assemblages are listed in order of decreasing total abundance, summed over 5209 -m long $\times 4$-m wide seine hauls

\begin{tabular}{|c|c|c|c|c|c|}
\hline $\begin{array}{l}\text { Group } \\
\text { Common name }\end{array}$ & Species or taxa & $\mathrm{n}$ & $\begin{array}{l}\text { Group } \\
\text { Common name }\end{array}$ & Species or taxa & $\mathrm{n}$ \\
\hline \multicolumn{2}{|c|}{ Unexploited invertebrates } & 43873 & Reef fishes & & 981 \\
\hline Hippolytid shrimp & Hippolyte spp. & 29735 & Pigfish & Orthopristis chrysoptera & 888 \\
\hline Grass shrimp & Palaemonetes spp. & 11173 & Sheepshead & Archosargus probatocephalus & $5 \quad 38$ \\
\hline Arrow shrimp & Tozeuma carolinense & 2655 & Gray snapper & Lutjanus griseus & 14 \\
\hline Sand shrimp & Crangon septemspinosa & 109 & Spottail pinfish & Diplodus holbrooki & 13 \\
\hline Snapping shrimp & Alpheus spp. & 103 & Gag grouper & Myctoperca microlepis & 7 \\
\hline Grass shrimp & Thor floridanus & 44 & Sergeant major & Abudefduf saxatalis & 7 \\
\hline Spider crab & Libinia dubia & 15 & Tautog & Tautoga onitis & 6 \\
\hline Atlantic mud crab & Panopeus herbstii & 15 & Planehead filefish & Monocanthus hispidus & 4 \\
\hline Small mud crab & Neopanope sayi & 14 & Black sea bass & Centropristis striata & 2 \\
\hline Pea crabs & Pinnixa spp. & 7 & Mahagony snapper & Lutjanus mahogoni & 2 \\
\hline Harris mud crab & Rithropanopeus harrisii & 2 & Benthic transients & & 478 \\
\hline Peppermint shrimp & Lysmata wurdemanni & 1 & Flagfin mojarra & Eucinostomus melanopterus & 112 \\
\hline \multicolumn{2}{|l|}{ Fished invertebrates } & 4352 & Southern flounder & Paralichthys lethostigma & 107 \\
\hline \multicolumn{2}{|c|}{ Unidentified juvenile penaeid shrimp } & 2444 & Summer flounder & Paralichtys dentatus & 73 \\
\hline Blue crab & Callinectes sapidus & 1332 & Spotfin mojarra & Eucinostomus argenteus & 53 \\
\hline White shrimp & Litopenaeus setiferus & 263 & Silver jenny & Eucinostomus gula & 44 \\
\hline Brown shrimp & Farfantepenaeus aztecus & 176 & Inshore lizardfish & Synodus foetens & 33 \\
\hline Pink shrimp & Farfantepenaeus duorarum & 129 & Blackcheek tonguefish & Symphurus plagusia & 25 \\
\hline Florida stone crab & Menippe mercenaria & 8 & Gulf flounder & Paralichthys albigutta & 16 \\
\hline Tatolinyort & & & Southern hake & Urophycis floridana & 8 \\
\hline \multirow{3}{*}{\multicolumn{2}{|c|}{ Total invertebrates }} & 48225 & Northern searobin & Prionotus carolinus & 4 \\
\hline & & & Bighead searobin & Prionotus tribulus & 1 \\
\hline & & & Irish pompano & Diapterus auratus & 1 \\
\hline \multirow{2}{*}{$\begin{array}{l}\text { Pinfish } \\
\text { Pinfish }\end{array}$} & \multirow{2}{*}{ Lagodon rhomboides } & \multirow{2}{*}{24540} & Yellowfin mojarra & Gerres cinereus & 1 \\
\hline & & & Benthic residents & & 470 \\
\hline Sciaenids & & 13440 & Dusky pipefish & Syngnathus floridae & 189 \\
\hline Spot & Leiostomus xanthurus & 11945 & Oyster toadfish & Opsanus tau & 109 \\
\hline Atlantic croaker & Micropogonias undulatus & 1290 & Naked goby & Gobiosoma bosc & 37 \\
\hline Silver perch & Bairdiella chrysoura & 203 & Mummichog & Fundulus heteroclitus & 29 \\
\hline Spotted seatrout & Cynoscion nebulosus & 1 & Speckled worm eel & Myrophis punctatus & 22 \\
\hline Weakfish & Cynoscion regalis & 1 & Rainwater killifish & Lucania parva & 14 \\
\hline Pelagic fishes & & 1747 & Darter goby & Gobionellus boleosoma & 14 \\
\hline Bay anchovy & Anchoa mitchilli & 1098 & Chain pipefish & Syngnathus louisianae & 13 \\
\hline Striped anchovy & Anchoa hepstus & 291 & Northern pipefish & Syngnathus fuscus & 10 \\
\hline Atlantic silverside & Menidia menidia & 232 & Striped blenny & Chasmodes bosquianus & 8 \\
\hline Inland silverside & Menidia beryllina & 43 & Feather blenny & Hypsoblennius hentz & 7 \\
\hline Rough silverside & Membras martinica & 41 & Code goby & Gobiosoma robustum & 6 \\
\hline Striped mullet & Mugil cephalus & 23 & Sheepshead minnow & Cyprinodon variegates & 5 \\
\hline American halfbeak & Hyporhamphus meek & 12 & Green goby & Microgobius thallassinus & 5 \\
\hline Atlantic needlefish & Strongylura marinani & 6 & Freshwater goby & Gobionellus shufeldti & 2 \\
\hline Northern sennet & Sphyraena borealis & 1 & Total fish & & 1656 \\
\hline
\end{tabular}

zed day and night catches separately using analogous 2-way factorial ANOVAs. Prior to all 3- and 2-factor ANOVAs, we performed Cochran's C-tests for homogeneity of variances, finding that transformations were unnecessary to meet this assumption of ANOVA. Consistent with serious concerns over the highly conservative nature of Bonferroni and other adjustments of alpha to address the rate of false discovery in applying multiple tests (e.g., Quinn \& Keough 2002), we present $\mathrm{p}$-values without modification for having tested 10 assemblages by day and night. For all 2-way ANOVAs, post hoc contrasts of main effects were performed using SNK tests (Day \& Quinn 1989). Where the interaction between sampling date and habitat proved statistically significant, multiple comparisons of habitat means within each date were also performed using the SNK procedure, which applies experiment-wise significance levels on the assumption of use of the full suite of paired contrasts. Using the results of pair-wise post hoc contrasts for each sampling date, we compiled an overall summarization of habitat contrasts over all dates for each assemblage. We first examined the out- 


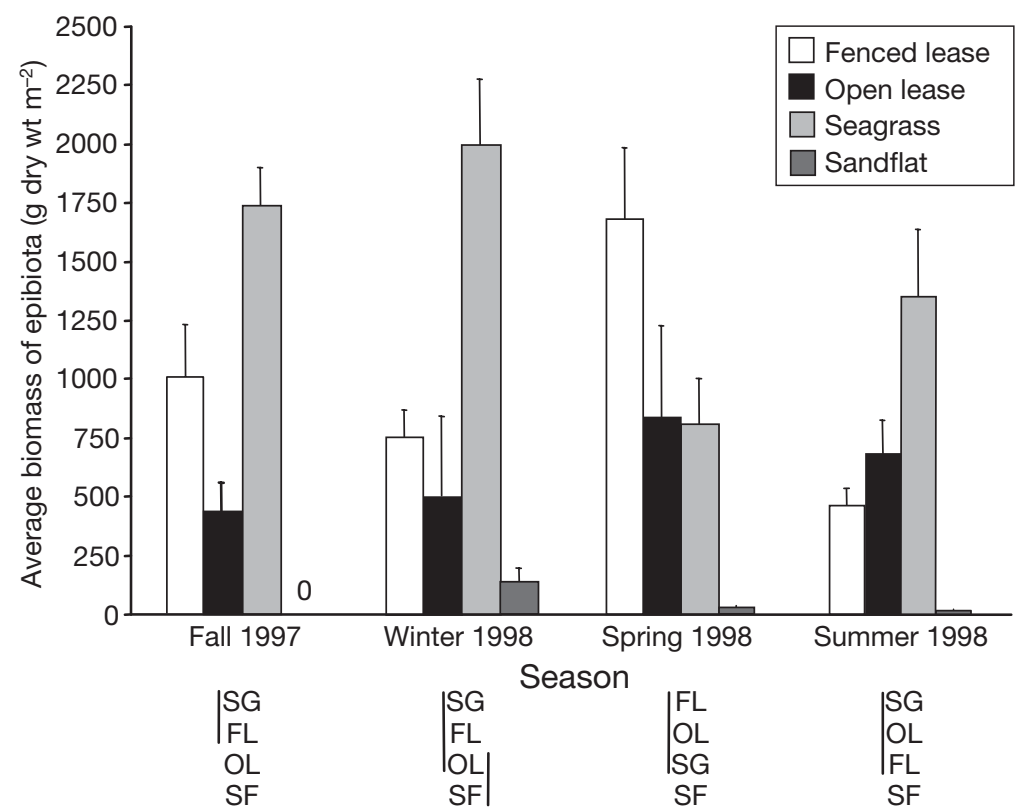

Fig. 2. Mean $(+\mathrm{SE}, \mathrm{n}=3)$ dry weight of biogenic biomass in each of 4 habitat types (fenced lease, FL; open lease, OL; seagrass, SG; sandflat, SF) during 4 seasons. Results of SNK comparisons within each season are presented at bottom of figure, where vertical lines connect treatments that do not differ significantly at $\alpha=0.05$

come of all pair-wise contrasts of each assemblage on every date when that assemblage was represented. For each assemblage, we then characterized overall relationships between habitats by reporting contrast outcomes that occurred on a majority of dates.

\section{RESULTS}

\section{Emergent biogenic habitat}

The polypropylene meshes enclosing and covering the clams on leases supported abundant macroalgal and attached epifaunal growth across all seasons. Although the mesh netting, which along with seed clams was installed clean in March 1997, remained undisturbed until after our last sampling in April 1999, no compelling pattern of temporally increasing biomass of epibiota is evident in our sampling results (Fig. 2). The taxa of the mostly attached (but also occasional drift) macroalgae included (in order of relative contribution to biomass) Codium spp., Dictyota dichotoma, Enteromorpha spp., Fucus vesiculosus, Padina gymnospora, Ulva spp., Gracilaria tikvahiae, Hypnea musciformis, and Sargassum filipendula. Macroalgae dominated
(>85\%) the dry weight of biogenic structural habitat material on the lease habitats, which included only small quantities of attached epifauna (5 to $15 \%$ ), consisting mostly of sessile, long-lived taxa such as the bryozoans Amathia spp. and Bugula neritina, the tunicate Styela plicata, and the sea whip Leptogorgia virgulata. The macroalgae and epifauna formed an irregular, 5 to $30 \mathrm{~cm}$ high canopy over the polypropylene mesh; this was similar to blade heights observed in the seagrass habitat. Biogenic biomass in the seagrass habitat was dominated ( $>90 \%$ ) by eelgrass Zostera marina and shoal grass Halodule wrightii, with smaller amounts (5 to $10 \%$ ) of attached epifauna and seasonal drift algae. The mean dry weight of total biogenic biomass varied from $459 \mathrm{~g} \mathrm{~m}^{-2}$ in summer 1998 to $1678 \mathrm{~g} \mathrm{~m}^{-2}$ in spring 1998 in the fenced lease, and from $437 \mathrm{~g} \mathrm{~m}^{-2}$ in fall 1997 to $842 \mathrm{~g} \mathrm{~m}^{-2}$ in spring 1998 in the open lease habitat (Fig. 2). In the seagrass habitat, mean biogenic dry weight ranged from $813 \mathrm{~g} \mathrm{~m}^{-2}$ in spring 1998 to $1996 \mathrm{~g} \mathrm{~m}^{-2}$ in winter 1998. The mean dry weight of biogenic material in the sandflat habitat remained low, ranging from $0 \mathrm{~g} \mathrm{~m}^{-2}$ in fall 1997 to $136 \mathrm{~g} \mathrm{~m}^{-2}$ in winter 1998.

The mean biomass of dried biogenic materials exhibited very highly significant $(p<0.001)$ variation with season, habitat type, and their interaction (Table 2). Despite the interaction, pairs of habitat types demonstrated a temporally consistent pattern (Fig. 2) of greater biogenic biomass in seagrass and in fenced and open leases than in the sandflat (significant in 4 of 4 seasons for seagrass and the fenced lease habitats and 3 of 4 seasons for the open lease). Biogenic biomass did not differ between seagrass and the fenced lease in any season or between seagrass and

Table 2. Results of 2-way factorial ANOVA examining effect of season (fixed: fall 1997, winter 1998, spring 1998, summer 1998), habitat type (fixed: fenced lease, open lease, seagrass, sandflat) and their interaction on the $\ln (x+1)$-transformed dry weight of biogenic structural biomass $\mathrm{m}^{-2}$. p-values in bold are statistically significant at $\alpha=0.05$. Habitat means by season and results of contrasts between habitats are shown in Fig. 2

\begin{tabular}{|lrrrrr|}
\hline Dependent variable & df & SS & MS & $F$ & $p$ \\
\hline Season & 3 & 6.88 & 2.29 & 6.89 & $\mathbf{0 . 0 1}$ \\
Habitat & 3 & 194.05 & 64.68 & 194.58 & $<\mathbf{0 . 0 1}$ \\
Season $\times$ Habitat & 9 & 32.07 & 3.56 & 10.72 & $<\mathbf{0 . 0 1}$ \\
Error & 32 & 10.64 & 0.33 & & \\
\hline
\end{tabular}


the open lease for 3 of 4 seasons. On average, however, the biomass of biogenic materials on the leases was only $55 \%$ of that of in seagrass habitat. Contrasts between lease types showed no difference in 3 of 4 seasons, although in one season (fall 1997) the fenced lease contained higher biogenic biomass than the open lease. Biomass of the biogenic structural habitat materials was lower in spring than in fall or winter for the seagrass habitat and higher in spring than in summer for the fenced lease, whereas no contrast was significant $(p<0.05)$ for the open lease. The sandflat habitat had its greatest biogenic habitat biomass in winter and none in fall, with summer and spring at intermediate levels significantly different from both other seasons (Fig. 2).

\section{Habitat use by mobile invertebrates and juvenile fishes}

\section{General patterns}

We collected 48225 mobile invertebrates and 41656 fish in a total of 520 seine hauls (11 sampling dates $\times 4$ habitats $\times 2$ diel periods $\times 6$ replicates $=528$ collected, 8 were lost), half at night and half during the day. Assemblages were defined by grouping taxa (Table 1), using finer taxonomic discrimination (species level) and functional groupings for the fishes, which were the primary focus of this study. Among the invertebrates (54\% of the total catch), unexploited invertebrates comprised $49 \%$ and fished invertebrates $5 \%$ of the totals. Among the fishes $(46 \%$ of the total catch), pinfish were the most abundant species and 'assemblage' (27\% of total catch), followed by sciaenids $(15 \%)$, pelagics $(2 \%)$, reef fishes, defined by adult habitat association $(1 \%)$, benthic transients $(<1 \%)$, and benthic residents $(<1 \%)$. We identified 73 invertebrate and fish taxa from the combined day and night seine surveys, with cumulative taxonomic richness highest in the open lease (65) and seagrass (65), followed by fenced lease (53) and sandflat (40) habitats. Average numbers of invertebrates per seine haul were highest in seagrass with 334 (46\% of the total), followed by the fenced lease with $208(27 \%)$ and the open lease with $188(26 \%)$, each of which was dramatically higher than the sandflat with $4(<1 \%)$ (Fig. 3a). The average numbers of fish captured per seine haul were highest in the open lease at 286 (45\%), followed by seagrass at 168 $(27 \%)$, fenced lease at $140(22 \%)$, and sandflat at 38 (6\%) (Fig. 3b).

\section{Patterns of community composition}

The nMDS ordination based upon average abundances of all taxa in the 8 habitat $\times$ time groupings indicated a high degree of similarity in composition of the community of juvenile fishes and mobile invertebrates among the 3 structured habitats, all of which differed from the 2 sandflat points (Fig. 4). Within each habitat, day and night differed in community composition. The day-night difference was similar in both magnitude and direction in the bivariate plot for each of the 3 structured habitats. However, the composition of the community changed much more between night
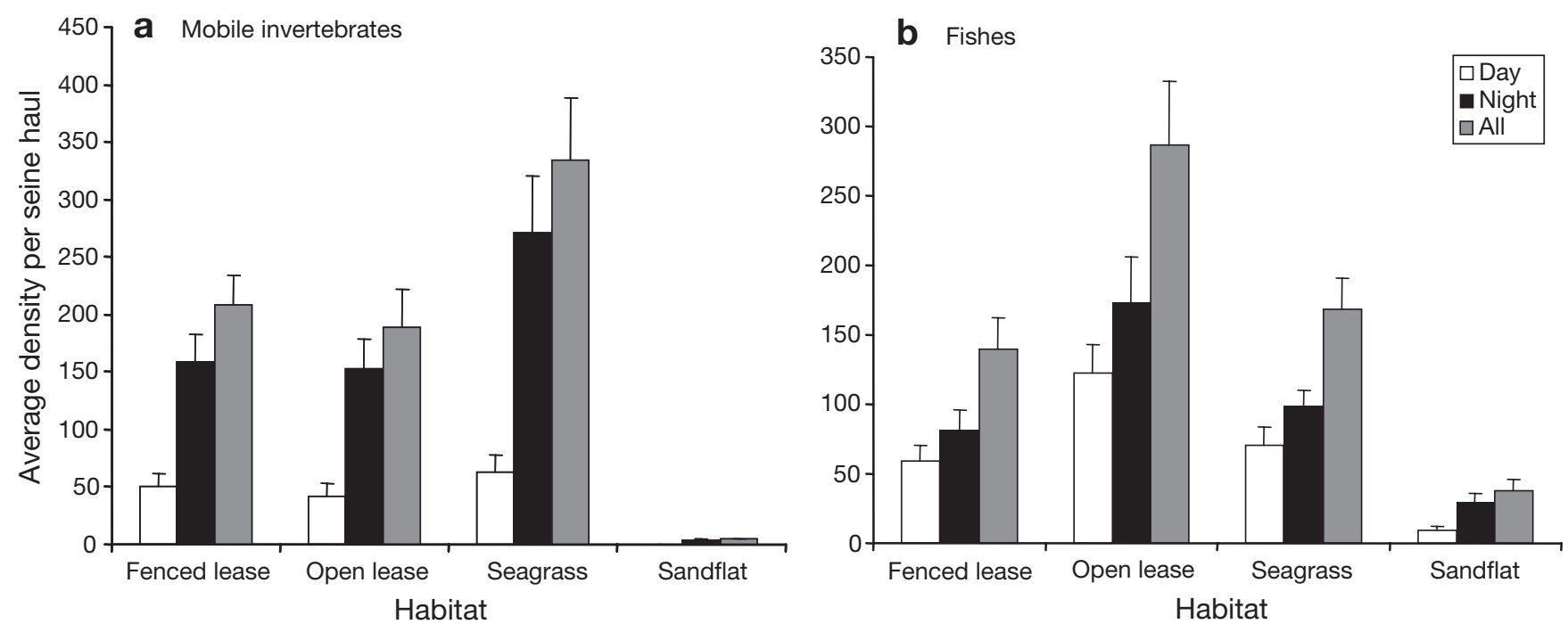

Fig. 3. Average numerical density ( $+1 \mathrm{SE}, \mathrm{n}=65,65,130$ for day, night, all times, respectively) per $9 \times 4 \mathrm{~m}$ seine haul of (a) total mobile invertebrates and (b) total fishes captured during day and night in each of 4 habitat types. (See Table 3 for results of statistical analysis) 


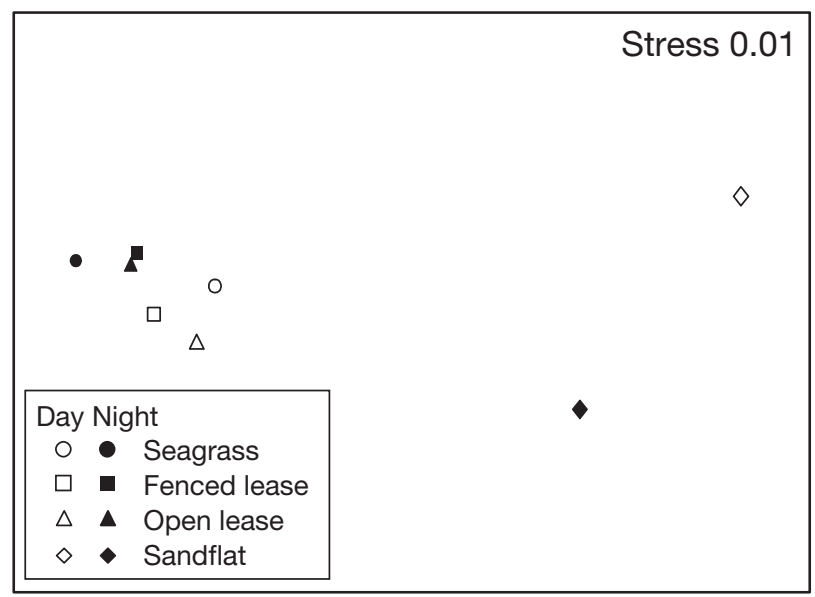

Fig. 4. Results of non-metric multidimensional scaling (nMDS) ordination by PRIMER of mean densities of mobile invertebrates and fishes using all identified taxa captured during day and night seine surveys in each of 4 habitat types. Stress $<0.15$ indicates good 2-dimensional representation of pattern of dissimilarity (Clarke \& Warwick 2001)

and day on the sandflat and changed in the opposite direction from the diel shift exhibited by all 3 structured habitats (Fig. 4). The groups most responsible for the diel dichotomy on the sandflat were sciaenids (dominated by spot), but also included pelagics (mostly anchovies and silversides), pinfish, and fished invertebrates (mostly penaeid shrimps, blue crab). In structured habitats, the unexploited invertebrates contributed most to the relatively modest diel change in community composition, with sciaenids involved to a lesser degree.
Analysis of density patterns

Total densities of both mobile invertebrates and of juvenile fishes captured by seining revealed highly significant $(p<0.01)$ variation with sampling date, habitat type, sampling time, and all their interactions (Table 3). Likewise, most 3-way (date $\times$ habitat $\times$ time) and many 2 -way interactions were also highly significant in analyses of each of the 8 taxonomic/functional assemblages (Table 3). Without exception, total numbers of mobile invertebrates and of juvenile fishes increased from day to night in each habitat and did so in a fashion that largely preserved the pattern of differences among habitats, despite the significant 3-way interactions (Fig. 3). Subsequent 2-factor ANOVAs done separately for day (Table 4) and night (Table 5) demonstrated highly significant effects of sampling date, habitat type, and their interaction for both total invertebrate and total fish densities, as well as for most of the 8 assemblages, resulting in the need to compare habitats on each sampling date.

Synthesizing the results of the SNK contrasts from each sampling date to establish general patterns among habitats in mobile invertebrate and juvenile fish use showed that only trivial differences existed between day (Table 4) and night (Table 5) in patterns of habitat use. The habitat use pattern for total invertebrates was identical for day and night, but for total fish one difference emerged. Total fish abundance did not differ between the 2 lease habitats during the day (Table 4) but was significantly higher in the open than in the fenced lease at night (Table 5). Similarly, each of the 8 taxonomic/functional assemblages exhibited high day-night similarity in patterns of habitat use,

Table 3. Summary of ANOVAs showing p-values (bold = statistically significant at $\alpha=0.05$ ) from identical 3-way factorial ANOVAs examining effects of date (fixed: 11 dates from August 1997 to April 1999), habitat type (fixed: fenced lease, open lease, seagrass, sandflat), sampling time (fixed: day, night), and their interactions on the densities of each of 10 taxonomic/functional assemblages sampled by 6 replicate seine hauls per treatment combination. Means for total invertebrates and total fish are pooled across dates by day and by night in Fig. 3 and by sampling date at night in Figs. 5 (invertebrates) or 6 (fish)

\begin{tabular}{|c|c|c|c|c|c|c|c|}
\hline Dependent variable & Date & Habitat & Time & $\begin{array}{c}\text { Date } \times \\
\text { Habitat }\end{array}$ & $\begin{array}{c}\text { Date } \times \\
\text { Time }\end{array}$ & $\begin{array}{c}\text { Habitat } \times \\
\text { Time }\end{array}$ & $\begin{array}{c}\text { Date } \times \\
\text { Habitat } \times \\
\text { Time }\end{array}$ \\
\hline Total invertebrates & $<0.01$ & $<0.01$ & $<0.01$ & $<0.01$ & $<0.01$ & $<0.01$ & $<0.01$ \\
\hline Unexploited & $<0.01$ & $<0.01$ & $<0.01$ & $<0.01$ & $<0.01$ & $<0.01$ & $<0.01$ \\
\hline Fished & $<0.01$ & $<0.01$ & $<0.01$ & $<0.01$ & $<0.01$ & $<0.01$ & $<0.01$ \\
\hline Total fish & $<0.01$ & $<0.01$ & $<0.01$ & $<0.01$ & $<0.01$ & 0.35 & $<0.01$ \\
\hline Pinfish & $<0.01$ & $<0.01$ & 0.38 & $<0.01$ & 0.01 & 0.98 & $<0.01$ \\
\hline Sciaenids & $<0.01$ & $<0.01$ & $<0.01$ & $<0.01$ & $<0.01$ & 0.01 & $<0.01$ \\
\hline Pelagics & $<0.01$ & $<0.01$ & 0.09 & $<0.01$ & $<0.01$ & $<0.01$ & $<0.01$ \\
\hline Reef fishes & $<0.01$ & $<0.01$ & $<0.01$ & $<0.01$ & $<0.01$ & $<0.01$ & $<0.01$ \\
\hline Benthic transients & $<0.01$ & 0.14 & $<0.01$ & 0.34 & 0.03 & 0.51 & 0.57 \\
\hline Benthic residents & $<0.01$ & $<0.01$ & $<0.01$ & $<0.01$ & 0.57 & 0.01 & 0.04 \\
\hline
\end{tabular}


with only 4 minor changes. First, fished invertebrate abundance was similar among all habitat types during the day (Table 4), but higher at night in the seagrass than in the sandflat and fenced lease habitats (Table 5). Second, pinfish abundance was not higher on the fenced lease than in the sandflat habitats during the day, but was so at night, thereby rendering use of all 3

Table 4. Summary of ANOVAs showing p-values (bold = statistically significant at $\alpha=0.05$ ) from identical 2-way factorial ANOVAs examining the effect of date (fixed: 11 dates from August 1997 to April 1999), habitat type (fixed: fenced

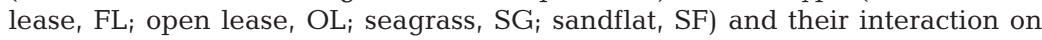
densities of each of 10 taxonomic/functional assemblages sampled by daytime seining using 6 replicate hauls per treatment combination. This post hoc summary shows patterns of all habitat differences in pair-wise Student-Neuman-Keuls (SNK) contrasts detected as significant on a majority of dates. Habitat types are listed from left to right in order of decreasing density and lines connect treatments that do not differ significantly on the majority of dates; -: no post-hoc tests of habitat differences performed because of lack of habitat effects in the ANOVA

\begin{tabular}{|lrrrr|}
\hline Dependent variable & Date & Habitat & $\begin{array}{c}\text { Date } \times \\
\text { Habitat }\end{array}$ & Post hoc summary \\
\hline Total invertebrates & $<\mathbf{0 . 0 1}$ & $<\mathbf{0 . 0 1}$ & $<\mathbf{0 . 0 1}$ & SG FL OL SF \\
Unexploited & $<\mathbf{0 . 0 1}$ & $<\mathbf{0 . 0 1}$ & $<\mathbf{0 . 0 1}$ & SG FL OL SF \\
Fished & $\mathbf{0 . 0 1}$ & $<\mathbf{0 . 0 1}$ & $<\mathbf{0 . 0 1}$ & SG OL FL SF \\
Total fish & $<\mathbf{0 . 0 1}$ & $<\mathbf{0 . 0 1}$ & $<\mathbf{0 . 0 1}$ & OL SG FL SF \\
Pinfish & $<\mathbf{0 . 0 1}$ & $<\mathbf{0 . 0 1}$ & $<\mathbf{0 . 0 1}$ & OL SG FL SF \\
Sciaenids & $<\mathbf{0 . 0 1}$ & $<\mathbf{0 . 0 1}$ & $<\mathbf{0 . 0 1}$ & OL FL SG SF \\
Pelagics & $<\mathbf{0 . 0 1}$ & $<\mathbf{0 . 0 1}$ & $<\mathbf{0 . 0 1}$ & OL FL SG SF \\
Reef fishes & $<\mathbf{0 . 0 1}$ & 0.08 & 0.15 & - \\
Benthic transients & $<\mathbf{0 . 0 1}$ & 0.06 & $<\mathbf{0 . 0 1}$ & OL FL SG SF \\
Benthic residents & $<\mathbf{0 . 0 1}$ & $<\mathbf{0 . 0 1}$ & $<\mathbf{0 . 0 1}$ & SG OL FL SF \\
& & & & \\
\hline
\end{tabular}

Table 5. Summary of ANOVAs showing p-values (bold = statistically significant at $\alpha=0.05$ ) from identical 2 -way factorial ANOVAs examining effect of date, habitat type and their interaction on densities of each of 10 taxonomic/functional assemblages sampled in night-time seining using 6 replicate hauls per treatment combination. Further details in legend to Table 4. Means are given by date and habitat for total invertebrates in Fig. 5 and for total fish in Fig. 6

\begin{tabular}{|c|c|c|c|c|}
\hline Dependent variable & Date & Habitat & $\begin{array}{c}\text { Date } \times \\
\text { Habitat }\end{array}$ & Post hoc summary \\
\hline Total invertebrates & $<0.01$ & $<0.01$ & $<0.01$ & $\overline{\text { SG FL OL SF }}$ \\
\hline Unexploited & $<0.01$ & $<0.01$ & $<0.01$ & $\overline{\text { SG FL OL SF }}$ \\
\hline Fished & $<0.01$ & $<0.01$ & $<0.01$ & $\overline{\mathrm{SG}} \underline{\mathrm{OL}} \mathrm{FL} \mathrm{SF}$ \\
\hline Total fish & $<0.01$ & $<0.01$ & $<0.01$ & $\overline{\mathrm{OL} \mathrm{SG}} \overline{\mathrm{FL} \mathrm{SF}}$ \\
\hline Pinfish & $<0.01$ & $<0.01$ & $<0.01$ & $\overline{\mathrm{OL}} \mathrm{SG}$ FL $\mathrm{SF}$ \\
\hline Sciaenids & $<0.01$ & $<0.01$ & $<0.01$ & OL $\overline{\text { FL SG SF }}$ \\
\hline Pelagics & $<0.01$ & $<0.01$ & $<0.01$ & $\overline{\text { OL SG SF FL }}$ \\
\hline Reef fishes & $<0.01$ & $<0.01$ & $<0.01$ & $\overline{\text { SG OL FL SF }}$ \\
\hline Benthic transients & $<0.01$ & 0.33 & $<0.73$ & - \\
\hline Benthic residents & $<0.01$ & $<0.01$ & $<0.01$ & $\overline{\mathrm{OL} \mathrm{SG} \mathrm{FL} \mathrm{SF}}{ }^{\mathrm{a}}$ \\
\hline
\end{tabular}

structured habitats greater than that of the sandflat at night. Third, sciaenids utilized all habitats equally durthe day, but were found in greater abundance in the open lease than in the sander the open lease than in the sandflat habitats. Because of the day/night similarity in general patterns of habitat use, we confine our detailed presentation of habitat patterns to the nighttime surveys, when most of both mobile invertebrates $(79 \%)$ and fishes $(61 \%)$ were captured and risk of bias from the possible effects of habitatdependent net avoidance was lower.

Although differences existed among dates in habitat use for both total invertebrates and total fish (producing the significant interactions between sampling date and habitat type), post hoc contrasts among habitats for each sampling date uncovered 3 repeatable patterns in nocturnal habitat use (Table 5). First, on no date did the sandflat possess significantly higher densities of mobile invertebrates (Fig. 5) or juvenile fishes (Fig. 6) than any of the structured habitats (seagrass, fenced and open leases). On a majority of dates, densities on the sandflat were significantly lower than on each structured habitat, except for the contrast with the fenced lease habitat for fish, where only 3 of the 10 mo of lower fish catches on the sandflat were significant (Fig. 6). Second, densities of mobile invertebrates (Fig. 5) and fishes (Fig. 6) in seagrass failed to exceed levels on the 2 lease habitats on most dates. Seagrass habitat ranked significantly higher than both lease habitats only 3 times for total invertebrate density and only twice for total fish density. For total fish, the seagrass habitat actually ranked significantly below the open lease on 4 dates and below the fenced lease on 2 dates (Fig. 6). Third, the 2 lease types did not differ from one another in a consistent fashion. For mobile invertebrates, no difference emerged on most dates and when differences were detected the fenced lease ranked higher 4 times, while the 


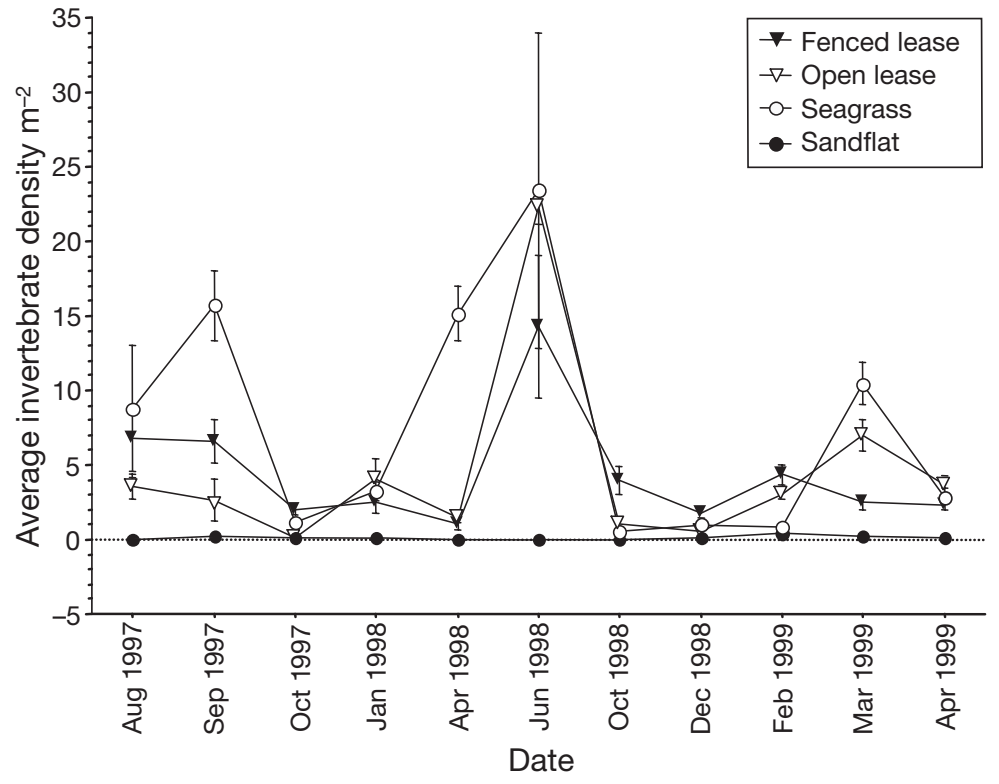

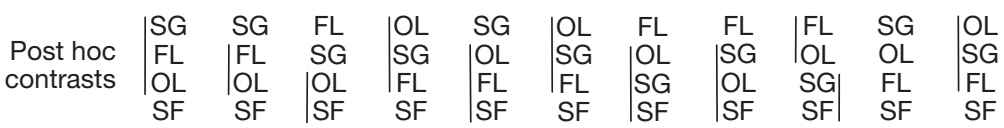

Fig. 5. Average $( \pm 1 \mathrm{SE}, \mathrm{n}=6)$ numbers $\mathrm{m}^{-2}$ of all mobile invertebrates captured during night-time seine surveys in 4 habitat types (fenced lease, FL; open lease, OL; seagrass, $\mathrm{SG}_{\text {; }}$ sandflat, $\mathrm{SF}$ ) on 11 sampling dates. Results of SNK comparisons within each date are presented at bottom of figure, where vertical lines connect treatments that do not differ significantly at $\alpha=0.05$. (See Table 5 for results of 2 -way ANOVAs)

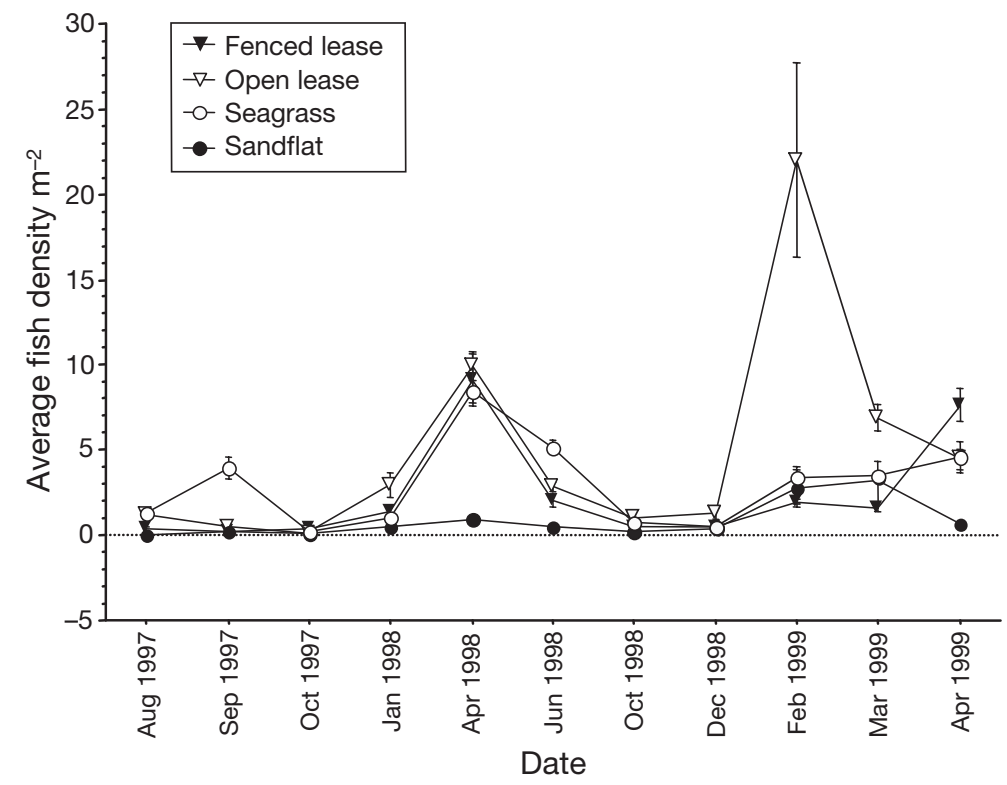

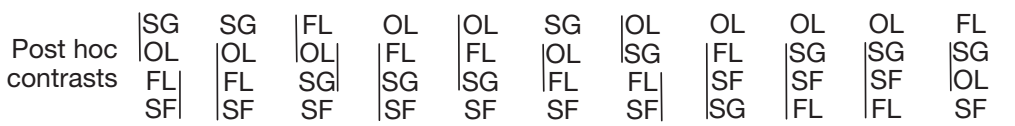

Fig. 6. Average $( \pm 1 \mathrm{SE}, \mathrm{n}=6)$ numbers $\mathrm{m}^{-2}$ of all fishes captured during night-time seine surveys in 4 habitat types. Further details in legend to Fig. 5; ANOVAs in Table 5 reverse occurred only once (Fig. 5). However, for total fish, the open lease had significantly higher densities on all 7 of the sampling dates when the leases differed (Fig. 6).

Both of the invertebrate and 5 of the 6 fish assemblages sampled at night exhibited highly significant sampling date, habitat type, and date $\times$ habitat interaction effects (Table 5). Only benthic transient fishes lacked main and interactive effects of habitat type. Unexploited invertebrates had an identical pattern to total invertebrates, with densities higher in structured habitats than on the sandflat and no consistent difference of occupation among structured habitats on a majority of sampling dates (Fig. 5). Fished invertebrates exhibited significantly higher densities in the seagrass than on both the sandflat and the fenced lease on each date and these latter 3 habitats did not differ from one another on a majority of dates (Fig. 5). Analyses of the pinfish revealed no density differences among the 3 structured habitats, with each significantly higher than the sandflat on a majority of dates (Fig. 6). Sciaenids were significantly more abundant in the open lease than in all other habitats on most dates, with no consistent differences among these 3 habitat types. Pelagics showed no consistent pattern of preferential habitat occupation. Reef fishes displayed significantly higher densities in the 3 structured habitats than on the sandflat and no significant differences among structured habitats on the majority of sampling dates. The subset of reef fishes recognized by the US National Marine Fisheries Service as currently or recently overfished (gray snapper, gag grouper, tautog, mahogany snapper, black sea bass) utilized only the lease habitats (41 individuals) and the seagrass (27 individuals). Finally, benthic resident fishes were significantly more abundant on the open lease than in the sandflat habitat on a majority of dates.

\section{DISCUSSION}

Our study of the habitat value of epibiota attached to bivalve aquaculture netting demonstrated that the plastic bottom mesh containing and covering hard clams Mercenaria mercenaria on a North Carolina shellfish lease supported seasonally persistent 
macroalgal and epifaunal growth equal, on average, to about $55 \%$ of the biomass of seagrasses, macroalgae, and attached epibiota in a nearby natural seagrass habitat (Fig. 2). Because the seagrasses themselves represented almost all of the biomass that we measured in the seagrass habitat and because about half of Zostera marina and Halodule wrightii biomass is below-ground (Duarte \& Chiscano 1999), the emergent biomass of epibiotic habitat on the aquaculture netting must have been very similar to that of the natural seagrass bed. The netting itself can also provide structural refuge habitat for fish and invertebrates, which is not included in our biomass figures.

Prior to establishment of aquaculture operations, the initial habitat type on the shellfish leases was largely unvegetated sandflat. Because epibiota is nearly absent from sandflats, occurring attached to occasional large shells, installation of bottom mesh served to enhance emergent structural habitat at the lease sites. In our study, the biomass density of epibiota on the aquaculture netting was on average 20 times greater than on the natural sandflat habitat nearby (Fig. 2). The season of greatest epibiotic biomass on the aquaculture netting was spring (April), when biomass of seagrasses, macroalgae, and epibiota in the seagrass habitat was least (Fig. 2), matching a general pattern of seasonal availability of seagrass habitat in North Carolina (Fonseca et al. 1990). Thus, the new habitat provided indirectly by the aquaculture operation may have special significance by seasonally augmenting potentially limited nursery habitat for species like pinfish and spot that recruit heavily to vegetated habitats in winter and spring (Levin et al. 1997, Ross 2003). Year-round, emergent epibiotic habitat on aquaculture netting may also partially compensate for anthropogenic losses of seagrass habitat (Orth \& Moore 1983).

Although quantification of biogenic structure may predict nursery habitat potential, comparisons of invertebrate and fish densities and community composition among habitat types directly quantify comparative habitat use (Heck et al. 2003). Seining demonstrated that enhancement of habitat structure by epibiotic growth on aquaculture netting installed in place of an unvegetated sandflat indeed resulted in substantially increased utilization by mobile invertebrates and juvenile fishes (Fig. 3). Compared to the sandflat, the seagrass habitat experienced 75 times as much use by mobile invertebrates and 3 times as much use by juvenile fish per unit area. The epibiotic habitat growing on aquaculture bottom netting provided much of this same effect, with a 42 (fenced lease) to 46 (open lease) -fold enhancement of mobile invertebrates and a 3 (fenced lease) to 7 (open lease)-fold enhancement of juvenile fishes (Fig. 3). Clearly, the provision of structured habitat in general had greater impact on mobile invertebrates as a group than on juvenile fishes, perhaps because without refuges mobile invertebrates experience higher risk of predation as a consequence of less mobility, smaller sizes, and (for decapod crustaceans) vulnerability during molting. The fenced lease enhanced fish utilization less than the open lease, probably because the fence, which was intended to exclude cownose rays, did indeed inhibit access by some fish. The mobile invertebrates, in contrast, exhibited a similar numerical response to both the fenced and open leases, probably because these invertebrates are not as mobile as fish and may migrate less among habitats. Community composition on leases was similar to that in the natural seagrass habitat and quite different from that over the sandflat habitat (Fig. 4), as expected from previous comparisons of faunal assemblages between vegetated habitats and unstructured bottom (e.g. Sogard \& Able 1991, Guidetti 2000, Heck et al. 2003).

Responses to availability of emergent biogenic habitat varied with taxonomic/functional assemblage of mobile invertebrates and juvenile fishes. Most of the organisms sampled were 'transients' (comprising 6 assemblages: pinfish, fished invertebrates, sciaenids, reef fishes, pelagic fishes, and benthic transients), defined as those taxa whose juvenile and adult habitats do not entirely overlap and thus those for whom the juvenile habitat may be most appropriately characterized as a nursery (Heck et al. 2003). Only members of 2 species assemblages (unexploited invertebrates and benthic resident fish) are generally considered permanent residents of seagrass. Individuals of these 2 assemblages were found almost exclusively in the 3 structured habitats (>99\% for unexploited invertebrates and $>98 \%$ for benthic resident fish). This pattern is likely to reflect a strong settlement preference for structured habitats, driven by selection to minimize predation by continuing to inhabit the structured canopy (Heck \& Thoman 1981, Summerson \& Peterson 1984). Of the 6 transient species assemblages, juvenile pinfish was the most common. The pinfish was treated as a separate assemblage because it comprised $59 \%$ of all fish sampled and because omnivorous foraging behavior (Weinstein et al. 1982, Luzcovich 1988) distinguishes it from members of other assemblages. Pinfish demonstrated a high affinity for vegetated habitats (as in Levin et al. 1997) during both day and night (Tables 4 \& 5). This pattern may reflect a joint effect of greater availability of plant and phytal invertebrate foods and greater protection from predators in vegetated habitats.

The component species of 3 assemblages, fished invertebrates, sciaenids, and reef fishes, have particular importance to commercial and recreational fisheries. Each of these assemblages exhibited relatively high 
utilization of lease habitats. Given the declines of several natural biogenically structured fish habitats in estuaries (e.g. seagrass beds, Dennison et al. 1993; saltmarshes and oyster reefs, Rothschild et al. 1994, Lenihan \& Peterson 1998), the biogenic-structured habitats of clam leases provide substitute nurseries that, if widespread enough, could make important contributions to sustaining these exploited populations. Blue crab populations have declined in recent years and are of such high value to fisheries that management to enhance their spawning stock and recruitment is urgently needed (Lipcius \& Stockhausen 2002). Reef fishes (gray snapper, gag grouper, mahogany snapper, tautog, and black seabass), whose stocks are depleted and/or are of management concern, utilized the lease habitats as intensely as the seagrass and none of the 69 individuals sampled came from the sandflat habitat. Reef fish in temperate estuaries are transients, typically recruiting in summer to inshore seagrasses, completing their early juvenile stages there and then migrating to offshore reef habitats in late fall (Levin \& Hay 2003). To the degree that provision of additional nursery habitat for these reef fishes enhances survival directly by reducing losses to predators (Hixon 1998) or indirectly by promoting faster fish growth (Peterson et al. 2003), clam aquaculture operations may contribute an important benefit to these depleted stocks.

The remaining 2 transient assemblages, pelagic and benthic transient fishes, displayed no consistent relationship with structured habitat by either day or night (Tables 4 \& 5). This lack of response to structured bottom habitats is understandable given that the atherinid (silversides) and engraulid (anchovies) fishes that dominated the pelagics occupy and feed from the water column rather than the bottom. Benthic transients (largely flatfish) did not show strong habitat preferences. Many flatfish are habitat generalists that can utilize a variety of habitat types within an estuarine landscape. Structured, vegetated habitats would not be expected to facilitate their habit of burying under a thin veneer of sand.

By seining during both day and night, we were able to assess how patterns of habitat use changed on a diel basis and test whether the similarity of use among biogenically structured habitats was robust to the daynight changes. As expected from previous evidence that predatory demersal fishes and blue crabs preferentially use protective cover of darkness to occupy and forage in unstructured sandflats (Summerson \& Peterson 1984), the sandflat habitat in our study exhibited much greater day-night community dissimilarity than any of the 3 structured habitat types (Fig. 4). The diel change in community composition on the sandflat habitat was driven largely by sciaenids, which doubled in nocturnal density on sandflats, and pinfish, which increased 4-fold, while changing only slightly in the 3 biogenically structured habitats. As might be anticipated from diel changes in mobile seagrass-associated invertebrates (e.g. Summerson \& Peterson 1984), fished invertebrates, mostly blue crabs and penaid shrimps, also contributed by increasing in nocturnal density by 30 -fold on sandflats but only by 4 - to 7 -fold in vegetated habitats. Despite this evidence of proportionately greater nocturnal use of unstructured sandflat habitat by some taxa, the patterns of affinity for biogenically structured habitat remained largely constant from day (Table 4) to night (Table 5). Even though high turbidity at all sampling seasons except winter implies that differential net avoidance is unlikely to have greatly biased even our daytime estimates of relative use of structured habitat, our focus on nocturnal sampling results confirms the robustness of patterns of preferential use of both natural seagrass and also biogenically structured lease habitats.

The results of our sampling and assessments of habitat use of algae-occupied clam aquaculture netting provide information that is needed to conduct a balanced evaluation of the impacts of bivalve aquaculture. Recent highly publicized reviews (Goldburg \& Triplett 1997, Naylor et al. 2000) have emphasized the negative impacts of aquaculture. Here we have shown that algal and epibiotic growth on the bottom mesh used in bivalve aquaculture (as practiced in North Carolina and elsewhere) can enhance the nursery habitat for the many species that preferentially associate with seagrass habitat, at least as juveniles. This previously undocumented benefit of bivalve aquaculture can increase the production and probably abundance of many forage species and fished species of mobile invertebrates and fish. Our demonstration is consistent with and adds to a broader recognition that artificial hard substrata in the marine environment that become occupied by epibiota serve effectively as a fish habitat. These include plastic seagrass mimics (Bell et al. 1985), rock jetties (Hay \& Sutherland 1988), artificial reefs and oil-drilling platforms (Love et al. 2005). In the wake of dramatic declines in all biogenically structured estuarine nursery habitats, including seagrass meadows (Orth \& Moore 1983, Dennison et al. 1993), salt marshes, and oyster reefs (Rothschild et al. 1994, Lenihan \& Peterson 1998), augmentation of usable habitat may help relax current bottlenecks in the early lifehistory survival of fish and invertebrates that support marine fisheries.

Thus, consideration of environmental consequences of bivalve aquaculture operations should add this nursery habitat benefit to the water quality benefits already identified (Goldburg \& Triplett 1997, Naylor et al. 2000, Jackson et al. 2001, Newell 2004). For example, around the margins of a large hard clam aqua- 
culture operation in Virginia, seagrass has increased substantially over the years of culturing clams (M. Pearson, Cherrystone Inc., pers. comm.), probably because of the clams' ability to reduce turbidity through filtration and thereby provide sufficient light for nearby seagrass growth. There are indeed environmental problems associated with poorly conceived bivalve aquaculture operations, but cautious and prudent management can reduce those risks (Folke \& Kautsky 1989). Juvenile shellfish used in aquaculture should be derived from gametes of locally collected parents and should include sufficient numbers of both sexes to minimize modification of genotypic composition and avoid reducing genetic diversity of wild stocks. Stocking densities should be controlled and varied as a function of flow regime to avoid organic overloading of the estuarine seafloor and consequent mortality of benthic organisms (Folke \& Kautsky 1989, Kaiser et al. 1998). Care should be taken that the mesh used to protect benthic shellfish from predation lies sufficiently flat on the bottom to avoid acting as a gill net and causing unintended mortality of small fishes. If such environmental concerns are satisfied, aquaculture of bivalve molluscs could provide important ecosystem services and public benefits that, once quantified, may be sufficient to regard such aquaculture as a means of mitigating for water quality degradation and loss of biogenically structured nursery habitats.

Acknowledgements. We thank D. Gaskill, J. Grabowski, K. Gregalis, G. Johnson, C. Jolicoeur, L. Manning, E. Sullivan, E. Southern, R. Mendosa, and G. Safrit for field and laboratory assistance. J. O'Neal and P. Brown assisted with data entry and M. Bishop assisted with data analyses. J. Bruno, J. Buckel, N. Lindquist, A. Moran, and 3 referees provided helpful comments on this manuscript. We express gratitude to Carolina Cultured Shellfish for access to their clam leases. This research was funded by the Fisheries Resources Grant Program of the North Carolina Legislature administered through NC Sea Grant (FRG97-AM-13).

\section{LITERATURE CITED}

Alpine AE, Cloern JE (1992) Trophic interactions and direct physical effects control phytoplankton biomass and production in an estuary. Limnol Oceanogr 37:946-955

Bell JD, Steffe AS, Westoby M (1985) Artificial seagrass: How useful is it for field experiments on fish and macroinvertebrates? J Exp Mar Biol Ecol 90:171-177

Bell SS, Hall MO, Robbins BD (1995) Toward a landscape approach in seagrass beds: using macroalgal accumulation to address questions of scale. Oecologia 104:163-168

Clarke KR, Warwick RM (2001) Changes in marine communities: an approach to statistical analysis and interpretation, 2nd edn. Plymouth Marine Laboratory, Plymouth

Cooper SR, Brush GS (1993) A 2500-year history of anoxia and eutrophication in Chesapeake Bay. Estuaries 16:617626
Day RW, Quinn GP (1989) Comparisons of treatments after an analysis of variance in ecology. Ecol Monogr 59:433-463

Dennison WC, Orth RJ, Moore KA, Stevenson JC, Carter V, Kollar S, Bergstrom PW, Batiuk RA (1993) Assessing water quality with submersed aquatic vegetation: habitat requirements as barometers of Chesapeake Bay Health. BioScience 43:86-94

Duarte CM, Chiscano CL (1999) Seagrass biomass and production: a reassessment. Aquat Bot 65:159-174

Folke C, Kautsky N (1989) The role of ecosystems for a sustainable development of aquaculture. Ambio 18:234-243

Fonseca MS, Kenworthy WJ, Colby DR, Rittmaster KA, Thayer GW (1990) Comparisons of fauna among natural and transplanted eelgrass Zostera marina meadows: criteria for mitigation. Mar Ecol Prog Ser 65:251-264

Goldburg R, Triplett T (1997) Murky waters: environmental effects of aquaculture in the US. Environmental Defense, New York (also available at: www.environmentaldefense.org/documents/490_AQUA)

Guidetti P (2000) Differences among fish assemblages associated with nearshore Posidonia oceanica seagrass beds, rocky-algal reefs and unvegetated sand habitats in the Adriatic Sea. Estuar Coast Shelf Sci 50:515-529

Hay ME, Sutherland JP (1988) The ecology of rubble structures of the South Atlantic Bight: a community profile. US Fish Wildl Serv Biol Rep 85 (7.20), Slidell, LA

Heck KL Jr, Thoman TA (1981) Experiments on predatorprey interactions in vegetated aquatic habitats. J Exp Mar Biol Ecol 53:125-134

Heck KL Jr, Hays G, Orth RJ (2003) Critical evaluation of the nursery role hypothesis for seagrass meadows. Mar Ecol Prog Ser 253:123-136

Hixon MA (1998) Population dynamics of coral-reef fishes: controversial concepts and hypotheses. Aust J Ecol 23: 192-201

Jackson JBC, Kirby MX, Berger WH, Bjorndal KA and 15 others (2001) Historical overfishing and the recent collapse of coastal ecosystems. Science 293:629-638

Jennings S, Kaiser MJ (1998) The effects of fishing on marine ecosystems. Adv Mar Biol 34:201-352

Kaiser MJ, Laing I, Utting SD, Burnell GM (1998) Environmental impacts of bivalve mariculture. J Shellfish Res 17: $59-66$

Kraeuter JN, Fegley S, Flimlin GE, Mathis G (1998) The use of mesh bags for rearing northern quahog (hard clam), Mercenaria mercenaria seed. J Shellfish Res 17:205-209

Lenihan HS, Peterson CH (1998) How habitat degradation through fishery disturbance enhances impacts of hypoxia on oyster reefs. Ecol Appl 8:128-140

Levin PS, Hay ME (2003) Selection of estuarine habitats by juvenile gags in experimental mesocosms. Trans Am Fish Soc 132:76-83

Levin PS, Petrik R, Malone J (1997) Interactive effects of habitat selection, food supply and predation on recruitment of an estuarine fish. Oecologia 112:55-63

Lipcius RN, Stockhausen WT (2002) Concurrent decline of the spawning stock, recruitment, larval abundance, and size of the blue crab Callinectes sapidus in Chesapeake Bay. Mar Ecol Prog Ser 226:45-61

Love MS, Schroeder DM, Lenarz WH (2005) Distribution of bocaccio (Sebastes paucispinis) and cowcod (Sebastes levis) around oil platforms and natural outcrops off California with implications for larval production. Bull Mar Sci 77:397-408

Luzcovich JJ (1988) The role of prey detection in the selection of prey by pinfish Lagodon rhomboides (Linnaeus). J Mar Biol Ecol 123:15-30 
Naylor RL, Goldburg RJ, Primavera JH, Kautsky N and 6 others (2000) Effect of aquaculture on world fish supplies. Nature 405:1017-1024

Newell RIE (2004) Ecosystem influences of natural and cultivated populations of suspension-feeding bivalve mollusks: a review. J Shellfish Res 23:51-61

Newell RIE, Koch EW (2004) Modeling seagrass density and distribution in response to changes in turbidity stemming from bivalve filtration and seagrass sediment stabilization. Estuaries 27:793-806

Nixon SW (1995) Coastal marine eutrophication: a definition, social causes, and future concerns. Ophelia 41:199-219

Orth RJ, Moore KA (1983) Chesapeake Bay: an unprecedented decline in submerged aquatic vegetation. Science 222:51-53

Paerl HW, Pinckney JL, Fear JM, Peierls BL (1998) Ecosystem responses to internal and watershed organic matter loading: consequences for hypoxia in the eutrophying Neuse River Estuary, North Carolina, USA. Mar Ecol Prog Ser 166:17-25

Paez-Osuna F, Guerrero-Galvan SR, Ruiz-Fernandez AC (1998) The environmental impacts of shrimp aquaculture and the coastal pollution in Mexico. Mar Pollut Bull 36: 65-75

Pauly D, Christensen V, Dalsgaard J, Froese R, Torres I (1998) Fishing down marine food webs. Science 279:860-863

Peterson CH, Summerson HC, Fegley SR (1987) Ecological consequences of mechanical harvesting of clams. Fish Bull (Wash DC) 85:281-298

Peterson CH, Fodrie FJ, Summerson CH, Powers SP (2001) Site-specific and density-dependent extinction of prey by schooling rays: generation of a population sink in top-

Editorial responsibility: Kenneth Sherman (Contributing Editor), Narragansett, Rhode Island, USA quality habitat for bay scallops. Oecologia 129:349-356

Peterson CH, Grabowski JH, Powers SP (2003) Estimating enhancement of fish production resulting from restoring oyster reef habitat: quantitative valuation. Mar Ecol Prog Ser 264:249-264

Quinn GP, Keough MJ (2002) Experimental design and data analysis for biologists. Cambridge University Press, Cambridge

Ross SW (2003) The relative value of different estuarine nursery areas in North Carolina for transient juvenile marine fishes. Fish Bull (Wash DC) 101:384-404

Rothschild BJ, Ault JS, Goulletquer P, Héral M (1994) Decline of the Chesapeake Bay oyster population: a century of habitat destruction and overfishing. Mar Ecol Prog Ser 111:29-39

Silvert W, Sowles JW (1996) Modeling environmental impacts of marine finfish aquaculture. J Appl Ichthyol 12:75-81

Sogard SM, Able KW (1991) A comparison of eelgrass, sea lettuce macroalgae, and marsh creeks as habitats for epibenthic fishes and decapods. Estuar Coast Shelf Sci 33:501519

Summerson HC, Peterson CH (1984) Role of predation in organizing benthic communities of a temperate-zone seagrass bed. Mar Ecol Prog Ser 15:63-77

Tegner MJ, Dayton PK (1999) Ecosystem effects of fishing. Trends Ecol Evol 14:261-262

Thrush SF (1986) The sublittoral macrobenthic community structure of an Irish sea-lough: effect of decomposing accumulations of seaweed. J Exp Mar Biol Ecol 96:199-212

Weinstein MP, Heck KL Jr, Giebel PE, Gates JE (1982) The role of herbivory in pinfish (Lagodon rhomboides): a preliminary investigation. Bull Mar Sci 32:791-795

Submitted: July 3, 2005; Accepted: October 23, 2006 Proofs received from author(s): May 21, 2007 